\title{
Fibrin/fibrinogen degradation products in cerebrospinal fluid of patients admitted to a psychiatric unit
}

\author{
RICHARD HUNTER, THOMAS THOMSON, C. M. REYNOLDS, \\ AND PAMELA M. PITCHER

\begin{abstract}
From the Friern Hospital, London, and the Department of Biological Reagents, Wellcome Research Laboratories, Beckenham, Kent
\end{abstract}

SYNOPSIS Paired cerebrospinal fluid (CSF) and serum samples collected from 81 of 241 patients admitted to a district psychiatric hospital during a six month period were assayed for fibrin/ fibrinogen degradation products (FDP) using a haemagglutination inhibition technique. FDP were found in all serum samples. Fifteen patients $(18.5 \%$ ) had FDP in the CSF (range $0 \cdot 7-3 \cdot 75 \mu \mathrm{g} / \mathrm{ml}$.) and of these $13(87 \%)$ had associated CSF protein abnormalities and $9(60 \%)$ were hypertensive. Mean serum FDP values were the same $(4.4 \mu \mathrm{g} / \mathrm{ml}$.) in patients with and without FDP in the CSF. Three patients had raised serum FDP concentrations but no FDP in the CSF. The evidence suggests that the presence of FDP in CSF indicates recent central nervous system damage. In this series the most common cause was vascular disease.

During breakdown of fibrinogen and fibrin by the enzyme plasmin several large soluble fragments are released which have antigenic similarity with the parent molecule and are called collectively fibrin/fibrinogen degradation products (Nussenzweig and Seligmann, 1960; Fletcher et al., 1962). Sensitive assay systems have been developed and the range of normal values in serum and urine established (Das et al., 1967; Clarkson et al., 1970). FDP are found as constituents of normal serum in $95 \%$ of healthy adults (Das et al., 1967). Raised levels ( $>10 \mu \mathrm{g} /$ $\mathrm{ml}$. at rest, $>20 \mu \mathrm{g} / \mathrm{ml}$. after challenge by exercise or intravenous injection of adrenaline) occur in thrombotic, inflammatory, or neoplastic conditions which involve fibrin deposition or fibrinogen leakage (Ruckley et al., 1970; Wilson et al., 1971). To our knowledge, the presence of FDP in cerebrospinal fluid (CSF) has not been reported before.

This investigation was undertaken as part of a long-term study of CSF protein in psychiatric patients: previous experience showed that some $20 \%$ of patients admitted to this unit have abnormalities which run parallel with their abnormal mental state (Hunter et al., 1969).

\section{METHODS}

Paired CSF and serum samples were obtained by standard techniques of lumbar and venepuncture within 72 hours of admission from 81 of a total of 241 patients during a six month period. The remaining 160 patients either did not stay long enough, were unwilling to cooperate, were judged not sufficiently ill to warrant full investigation, or tests could not be performed within the specified time.

Two millilitre aliquot samples of CSF and blood were transferred immediately after collection to separate bottles containing $0.75 \mathrm{mg}$ soya bean trypsin inhibitor and $10 \mathrm{u}$. bovine thrombin. As soon as the blood clotted the sample was centrifuged and the clear serum was drawn off. Samples were stored at $-20^{\circ} \mathrm{C}$ while awaiting testing.

FDP were assayed using the Wellcome FDP Kit (Wellcome Reagents Ltd) based on the original method described by Merskey et al. (1966). The sensitivity of the red cell tests was $0.5-0.7 \mu \mathrm{g} / \mathrm{ml}$. as standardized against fibrinogen. Samples were absorbed with formolized sheep cells to remove any 
TABLE

CLINICAL DETAILS OF 15 PATIENTS

\begin{tabular}{|c|c|c|c|c|c|c|}
\hline Sex & $\begin{array}{l}\text { Age } \\
(y r)\end{array}$ & $\begin{array}{l}\text { Blood pressure } \\
\quad(\mathrm{mmHg})\end{array}$ & $\begin{array}{l}\text { CSF protein } \\
(\mathrm{mg} / 100 \mathrm{ml} .)\end{array}$ & $\begin{array}{l}\text { CSF FDP } \\
(\mu g / m l .)\end{array}$ & $\begin{array}{l}\text { Serum FDP } \\
(\mu \mathrm{g} / \mathrm{ml} .)\end{array}$ & Clinical diagnosis \\
\hline $\mathbf{M}$ & 29 & $140 / 80$ & 80 & $1 \cdot 25$ & $3 \cdot 6$ & $\begin{array}{l}\text { Post-encephalitic defect state: hypersomnia, obesity, } \\
\text { echo-palilalia }\end{array}$ \\
\hline $\mathbf{M}$ & 29 & $120 / 80$ & 120 & 0.7 & $7 \cdot 5$ & Persistent excitement after subarachnoid haemorrhage \\
\hline $\mathbf{M}$ & 34 & $130 / 80$ & 65 & 0.7 & $4 \cdot 0$ & Klinefelter's syndrome \\
\hline $\mathbf{M}$ & 38 & $180 / 120$ & 80 & $1 \cdot 0$ & 1.9 & Collagen disease, ?disseminated lupus erythematosus \\
\hline $\mathbf{M}$ & 38 & $140 / 90$ & 70 & $1 \cdot 0$ & $4 \cdot 0$ & Postgastrectomy malabsorption syndrome; alcoholism \\
\hline $\mathbf{M}$ & 56 & $160 / 110$ & 70 & $3 \cdot 75$ & $5 \cdot 0$ & Cerebral vascular disease \\
\hline $\mathbf{M}$ & 62 & $210 / 110$ & 65 & $1 \cdot 8$ & $3 \cdot 8$ & Cerebral vascular disease; diabetes \\
\hline $\mathbf{F}$ & 46 & $120 / 80$ & 90 & 0.9 & $5 \cdot 0$ & Diabetes; old myocardial infarct; recurrent chorea \\
\hline $\mathbf{F}$ & 43 & $130 / 80$ & 80 & 0.7 & $10 \cdot 0$ & Treated cerebrospinal syphilis \\
\hline $\mathbf{F}$ & 51 & $160 / 90$ & 55 & $1 \cdot 0$ & $5 \cdot 0$ & Presenile dementia, ?arteriosclerotic \\
\hline $\mathbf{F}$ & 56 & $210 / 120$ & 35 & $1 \cdot 25$ & $5 \cdot 0$ & Subacute encephalitis \\
\hline $\mathbf{F}$ & 58 & $180 / 120$ & 185 & 0.7 & $1 \cdot 8$ & Allergic encephalopathy? \\
\hline $\mathrm{F}$ & 68 & $140 / 90$ & 210 & $1 \cdot 5$ & $2 \cdot 4$ & Right temporoparietal glioma \\
\hline $\mathbf{F}$ & 73 & $210 / 110$ & 50 & 0.7 & 1.9 & Cerebral vascular disease \\
\hline $\mathbf{F}$ & 74 & $130 / 90$ & 70 & $1 \cdot 25$ & $5 \cdot 0$ & Carcinoma of breast; senile dementia, ?arteriosclerotic \\
\hline
\end{tabular}

heterologous antibodies which might otherwise interfere with the assay. When testing CSF samples, $10 \%$ horse serum was added to the buffer used for preparing dilutions and reconstituting antiserum, otherwise the same procedure was followed as described in the kit using a $1: 1 \cdot 5$ dilution series for both standards and reagents.

\section{RESULTS}

FDP were found in CSF in 15 of the 81 patients tested $(18.5 \%)$ in concentrations ranging from $0 \cdot 7-3 \cdot 75 \mu \mathrm{g} / \mathrm{ml}$. The Table shows these patients' sex, age, blood pressure, CSF protein, and CSF and serum FDP content, and clinical diagnoses. Their serum FDP values ranged from 1.8 $10.0 \mu \mathrm{g} / \mathrm{ml}$. with a mean of $4.4 \mu \mathrm{g} / \mathrm{ml}$., and were within normal limits in all. Thirteen of the 15 $\left(87^{\circ} \%\right.$ ) had abnormal CSF protein concentrations (men $>60 \mathrm{mg} / 100 \mathrm{ml}$., women $>50 \mathrm{mg} /$ $100 \mathrm{ml}$.) by criteria previously laid down for this laboratory (Hunter et al., 1969), but there was no correlation between CSF protein and CSF FDP levels $(r=0.068 ; \mathrm{P}>0 \cdot 1)$. Nine of the $15(60 \%)$ were hypertensive, three mildly and six moderately to severely; five almost certainly and three probably suffered from cerebral vascular disease, the remaining seven from a variety of primary and secondary neurological conditions.

In contrast, of the 66 patients $(81.5 \%)$ in whom no FDP were found in the CSF, only 11 $(17 \%)$ had CSF protein abnormalities and 10 $(15 \%)$ were hypertensive. Mean serum FDP concentration of these patients was also $4.4 \mu \mathrm{g} /$ $\mathrm{ml}$. (range $0.5-36 \mu \mathrm{g} / \mathrm{ml}$.), but three had abnormal levels. These were: a man aged 72 years (serum FDP $36 \mu \mathrm{g} / \mathrm{ml}$.) with raised CSF gammaglobulin concentration ( $>10 \%$ of total protein) in whom necropsy showed bronchopneumonia and changes of senile dementia of unusuak distribution but no evidence of cerebral vascularo disease; a man 30 years of age with recurrent attacks of akinetic stupor (serum FDP $30 \mu \mathrm{g} / \mathrm{ml}$. and raised CSF protein concentration who presumably suffered from an unidentified brain-stem disturbance; and a demented woman aged 66 years (serum FDP $25 \mu \mathrm{g} / \mathrm{ml}$.) whose CSF protein content was also abnormal.

\section{DISCUSSION}

Raised serum FDP concentrations are found in conditions associated with intravascular clotting or blood vessel damage. It is therefore reasonable to suppose that vascular disease of or tissue damage in the nervous system may cause leakage of FDP into the CSF. The fact that mean serum FDP concentrations were the same in patients with and without FDP in the CSF, that all patients with FDP in the CSF had normal serum FDP concentrations, and that none of the three patients with raised serum FDP concentrations had FDP in the CSF, confirms that its source was local disease within the nervous system and not the result of spill-over from serum. The most 
common cause in our patients appears to have been vascular disease. If FDP in CSF behave as in serum (Ruckley et al., 1970), they should be cleared within a few days. The only evidence on this point is furnished by the patient with persistent excitement after subarachnoid haemorrhage: he showed FDP in the CSF initially but none were found on retesting four weeks later when his CSF protein had also fallen to normal. The presence of FDP in CSF was almost invariably associated with an abnormal CSF protein content, although there was no correlation between their levels. Furthermore, nearly half the patients in this series who had abnormal CSF protein concentrations had no CSF FDP. A possible explanation may be that abnormal CSF protein concentrations, once established, persist longer. If this is so, FDP in CSF may be a more sensitive indicator of either recency or activity of brain disease. In this connection, it is of interest that one patient with FDP in the CSF was proved to have a rapidly growing glioma. Such a finding may have prognostic significance as a pointer to a tumour's malignancy.

We thank the laboratory staff of Friern Hospital for their cooperation in this investigation; Dr. A. D. Dayan for the necropsy findings and neuropathological report; and Mr. C. J. Evans of the Wellcome Research Laboratories for technical assistance.

\section{REFERENCES}

Clarkson, A. R., Morton, J. B., and Cash, J. D. (1970). Urinary fibrin/fibrinogen degradation products after renal homotransplantation. Lancet, 2, 1220-1223.

Clarkson, A. R., MacDonald, M. K., Petrie, J. J. B., Cash, J. D., and Robson, J. S. (1971). Serum and urinary fibrin/ fibrinogen degradation products in glomerulonephritis. British Medical Journal, 3, 447-451.

Das, P. C., Allan, A. G. E., Woodfield, D. G., and Cash, J. D. (1967). Fibrin degradation products in sera of normal subjects. British Medical Journal, 4, 718-720.

Fletcher, A. P., Alkjaersig, N., and Sherry, S. (1962). Pathogenesis of the coagulation defect developing during pathological plasma proteolytic ('fibrinolytic') states. Journal of Clinical Investigation, 41, 896-916.

Hunter, R., Jones, M., and Malleson, A. (1969). Abnormal cerebrospinal fluid protein and gamma-globulin levels in 256 patients admitted to a psychiatric unit. Journal of Neurological Sciences, 9, 11-38.

Merskey, C., Kleiner, G. J., and Johnson, A. J. (1966). Quantitative estimation of split products of fibrinogen in human serum, relation to diagnosis and treatment. Blood, 28, 1-18.

Nussenzweig, V., and Seligmann, M. (1960). Analyse, par des méthodes immunochemiques, de la dégradation par la plasmine du fibrinogène humain et de la fibrine, à différents stades. Revue d'Hématologie, 15, 451-466.

Ruckley, C. V., Das, P. C., Leitch, A. G., Donaldson, A. A., Copland, W. A., Redpath, A. T., Scott, P., and Cash, J. D (1970). Serum fibrin/fibrinogen degradation products associated with postoperative pulmonary embolus and venous thrombosis. British Medical Journal, 4, 395-398.

Wilson, J. E., III, Frenkel, E. P., Pierce, A. K., Johnson, R. L., Jr., Winga, E. R., Curry, G. C., and Mierzwiak, D. S. (1971). Spontaneous fibrinolysis in pulmonary embolism. Journal of Clinical Investigation, 50, 474-480. 